\title{
Analysis of Capital Income, Inflation, and Effects Savings on Community Consumption in Ternate City, North Molucas
}

\author{
PRINCE CHARLES HESTON RUNTUNUWU
}

Faculty of Economics, KHAIRUN UNIVERSITY, INDONESIA, E-mail: princecharles@unkhair.ac.id

\begin{abstract}
This examination was led to gauge the factors that impact individuals' utilization design in Ternate City by utilizing the macroeconomic idea of the monetary factors to be contemplated, specifically pay per capita, swelling, and reserve funds. The populace and test in this investigation were individuals of Template City. The insightful strategy used to test theories is different relapse examination. In light of the consequences of examination on the impact of pay on pay. Expansion and reserve funds on society utilization in the city of Template from 2009 to 2018 by utilizing a various relapse model can be closed as follows. The Income Per Capita Variable has a huge beneficial outcome on the Community Consumption of Template City; the Inflation variable has a positive and unimportant impact on the Community Consumption of Tomato City. The investment funds variable has a negative and unimportant impact on local area utilization in the City of Template. The factors of per capita pay, expansion, and Savings together have a huge beneficial outcome on Community Consumption in Ternate City.
\end{abstract}

Keywords: Capital Incomes; Effect saving; Community Consumption.

JEL Classification: E20, E22, E21 


\title{
Análisis de los Ingresos de Capital, la Inflación y los Efectos del Ahorro en el Consumo Comunitario en la Ciudad de Ternate, Molucas del Norte
}

\author{
PRINCE CHARLES HESTON RUNTUNUWU \\ Faculty of Economics, KHAIRUN UNIVERSITY, INDONESIA, E-mail: princecharles@unkhair.ac.id
}

\begin{abstract}
RESUMEN
Este examen se llevó a cabo para medir los factores que impactan en el diseño de la utilización de los individuos en la ciudad de Ternate utilizando la idea macroeconómica de los factores monetarios a contemplar, específicamente la paga per cápita, la hinchazón y los fondos de reserva. La población y la prueba en esta investigación fueron individuos de la ciudad de Ternate. La estrategia perspicaz utilizada para probar las teorías es el examen de recaída diferente. A la luz de las consecuencias del examen sobre el impacto de la paga sobre la paga. La expansión y los fondos de reserva sobre la utilización de la sociedad en la ciudad de Template de 2009 a 2018 mediante la utilización de un modelo de recaída diferente se puede cerrar de la siguiente manera. La variable renta per cápita tiene un enorme resultado beneficioso en el consumo de la sociedad de la ciudad de Template; la variable inflación tiene un impacto positivo y sin importancia en el consumo de la sociedad de la ciudad de Tomate. La variable fondos de inversión tiene un impacto negativo y sin importancia en la utilización del área local de la Ciudad de Template. Los factores de la remuneración per cápita, la expansión y el ahorro tienen en conjunto un enorme resultado beneficioso sobre el Consumo Comunitario de la Ciudad de Ternate.
\end{abstract}

Palabras clave: Ingresos de capital; Efecto ahorro; Consumo comunitario.

Clasificación JEL: E20, E22, E21 


\section{Introduction}

Humans lives cannot be separated from consumption activities, both consumption in meeting basic needs such as food, clothing, shelter, and consumption activities to meet other needs. Consumption expenditure is inherent in every human being from birth, meaning that every person carries out consumption activities throughout his life. Therefore, consumption activities play an essential role in human life. Various goods are produced and offered to society to be used by society to meet their daily needs. The emergence of production activities is due to consumption activities or public demand. Consumption expenditure is one of the macroeconomic variables denoted by " $\mathrm{C}$ " taken from the English word "consumption" The concept of consumption is defined as the expenditure made by households on final goods and services to meet the needs of people. the person who made the expenditure (Dumairy, 2004)

The pattern of public consumption is tentatively influenced by many economic factors such as household internal economic factors with indicators of household income, household wealth, number of families, future family expectations (education, health, old-age insurance), while external economic factors of households with government policy indicators, inflation rates, interest rates price of goods/services and availability of goods needed and non-economic factors with indicators of personal taste, lifestyle, and environment of residence (Nanga, 2005; Raharja, 2004; Sadono, 2008) Household consumption expenditure is the minimum consumption for that household, namely the amount of consumption expenditure that must be made, even though there is no income. This household consumption expenditure is called autonomous consumption. The amount of income varies between society's strata, between urban and rural areas, and between provinces, regions, and countries. keynes in Sukirno, (2003) states, "a person's consumption is directly proportional to his income." The greater a person's income, the greater the consumption expenditure. The ratio of the amount of consumption expenditure to additional income is the marginal desire for consumption marginal property to the consumer (MPC). Meanwhile, additional income is called the marginal desire to save (Marginal prosperity to Save, MPS).

Income has a relationship with consumption and savings. Savings are strongly influenced by consumption because savings can be viewed as an income obtained from the bank's speculative motive. The inflation rate is also related to the pattern of public consumption; inflation causes a transition effect to substituted goods. Consumers will reduce purchases of relatively expensive goods and increase consumption expenditure on relatively cheap goods. The existence of inflation means that the price of all goods has increased. This will cause a substitution effect between consumption expenditure and savings. The increase in the general price level does not mean that the increase in the price of goods is proportional. This encourages consumers to shift their consumption from one good to another. High inflation will weaken people's purchasing power, especially domestic production, which in turn will reduce public confidence in the value of the national currency (Guritno, 1998). Efforts to reform people's economy in the Eastern Indonesia region, which are left behind due to the lack of infrastructure development such as roads, airports, ports, dams, including proper housing, are a priority. This also affects the distribution costs of goods and services so that the cost of living is high due to the scarcity of infrastructure and the high cost of transportation which has an impact on the inflation of the people's economy, as is the case with the economy of the people in North Maluku province, especially Ternate City.

Ternate City is one of the island cities with the third-highest cost of living in Indonesia, which has a more excellent developing prospect than other cities in North Maluku Province. One of the developments carried out is in transportation, which is always increasing every year, considering that the contribution of the merchant sector is the highest income to the economy of this Province. Therefore, it takes capital to distribute goods and services. Geographically, Ternate City, as an island city at the foot of an active volcano, has the advantageous potential to become a distribution center for goods distributed to and from Ternate City. The high cost of living in Template City is due to the economy of Template City, which still depends on imported products from other regions, not to 
mention the effects of the weather or the eruption of Mount Gamalama, which affects transportation and the scarcity of fuel which causes very volatile inflation. Economic inflation data for the City of Template is presented in the following table:

Table 1.1 Inflation Data for the City of Ternate in 2009-2018

\begin{tabular}{|c|c|c|c|c|c|}
\hline Year & $\begin{array}{c}\text { GROSS REGIONAL } \\
\text { DOMESTIC } \\
\text { PRODUCT } \\
\text { (Expenditure at } \\
\text { Constant Price) }\end{array}$ & $\begin{array}{l}\text { Ternate City } \\
\text { Population }\end{array}$ & $\begin{array}{l}\text { Income per } \\
\text { capita }\end{array}$ & $\begin{array}{l}\text { Public } \\
\text { Saving }\end{array}$ & $\begin{array}{l}\text { Public } \\
\text { Consumption }\end{array}$ \\
\hline 0 & 1 & 2 & 3 & 4 & 5 \\
\hline 2009 & $281,203,900,000.00$ & 184,473 & $18,292,361.48$ & $1,121,458.00$ & $9,457,092.00$ \\
\hline 2010 & $354,019.778,000.00$ & 185,705 & $22,876,267.93$ & $1,330,883.00$ & $10,243,968.00$ \\
\hline 2011 & $388,191,126,000.00$ & 192,425 & $24,208,359.16$ & $1,654,255.00$ & $10,535,304.00$ \\
\hline 2012 & $423,264,499,000.00$ & 197,664 & $25,695,99921$ & $1,758,393.00$ & $11,613,516.00$ \\
\hline 2013 & $455,741,642,000.00$ & 202,728 & $26,976,538.53$ & $2,029,884.00$ & $12,983,064.00$ \\
\hline 2014 & $495,647,981,000.00$ & 207,789 & $28,624,112.79$ & $2,013,150.00$ & $13.274,400.00$ \\
\hline 2015 & $535,775,424,000.00$ & 212,997 & $30,184,956.07$ & $2,307.856 .00$ & $13,182,840.00$ \\
\hline 2016 & $578,726,943,000.00$ & 218,028 & $31,852,437.83$ & $2,296,444.00$ & $14,808,156.00$ \\
\hline 2017 & $616,178,137,000.00$ & 223,111 & $33,141,071.68$ & $2,621,119.00$ & $19,092,432.00$ \\
\hline 2018 & $654,175,972,000.00$ & 228,105 & $34,414.465 .55$ & $2,480,297.00$ & $19,966,248.00$ \\
\hline
\end{tabular}

Table 1.1 explains that in the second quarter of 2013, the level of inflation rose until it touched $9.78 \%$. This was due to the government's policy regarding the price of fuel oil in July. However, in 2016 the inflation rate for the first quarter to the fourth quarter showed a downward trend, this shows that this is due to the reduced impact of the fuel price hike and the improvement in people's expectations of inflation, besides that the high savings rate has succeeded in submerging the overall inflation rate. In this regard, data from the Bank Indonesia Representative of North Maluku reports that out of 10 districts/cities in North Maluku, the GRDP of Ternate City contributed $27 \%$ of the Provincial GRDP. Followed by North Halmahera at $15 \%$, South Halmahera at $14 \%$, Tidore Islands with 7\%. (Antarnews.com, 2017). Description of the economy of the City of Ternate in a study is shown in the following table:

Table 1.2 GRDP Expenditure, Total Population, Income per capita, Savings and Community Consumption of Ternate City in 2009 to 2018

\begin{tabular}{|c|c|c|c|c|c|c|c|c|c|}
\hline \multirow{2}{*}{ Month } & \multicolumn{9}{|c|}{ Inflation (\%) } \\
\hline & 2009 & 2010 & 2011 & 2012 & 2013 & 2014 & 2015 & 2016 & 2017 \\
\hline January & 0.41 & 1.53 & -0.32 & -0.14 & 0.45 & 0.45 & -0.55 & 0.52 & 0.63 \\
\hline February & 0.47 & 1.45 & 1.45 & 0.78 & 0.49 & -0.69 & -0.83 & -0.95 & 0.03 \\
\hline March & 1.25 & 1.79 & 0.79 & 0.11 & 0.49 & 0.53 & 0.35 & 0.28 & -0.31 \\
\hline April & 2.16 & 0.57 & 0.57 & 0.85 & 0.13 & 0.07 & 0.62 & 0.05 & 0.36 \\
\hline May & 2.06 & 0.70 & 0.70 & 0.34 & -0.21 & -0.11 & 0.65 & 0.29 & 0.2 \\
\hline June & 0.98 & 0.51 & 0.52 & 0.64 & 0.22 & 1.29 & 0.89 & 0.3 & 1.55 \\
\hline Juli & 1.16 & 0.72 & 1.72 & 1.36 & 6.04 & 2.55 & 0.9 & 1.04 & 0.08 \\
\hline August & 1.46 & 3.69 & 3.69 & 0.47 & 3.66 & -1.02 & 1.56 & -0.1 & -0.51 \\
\hline September & 2.3 & 3.10 & 3.10 & 1.11 & -2.39 & 0.87 & -1.58 & 0.09 & -0.51 \\
\hline October & 2.49 & 3.11 & 3.11 & 0.84 & 0.44 & 0.96 & 0.91 & 0.21 & 0.52 \\
\hline November & 2.92 & 4.12 & 4.12 & 0.95 & -0.29 & 0.41 & 0.02 & 0.26 & -1.06 \\
\hline December & 3.88 & 5.32 & 5.32 & 0.77 & 0.84 & 3.11 & 1.53 & 0.32 & 1.29 \\
\hline Year & 3.76 & 3.96 & 4.52 & 3.29 & 9.78 & 9.34 & 4.52 & 1.91 & 1.97 \\
\hline
\end{tabular}

Note: *) Preliminary estimation figures (based

**) Estimated figures are very preliminary Source:

1. The Year 2009 to 2016: BPS Ternate City website

2. Ternate City in Numbers

3. Per capita income: Processed data (PDRB divided by total population multiplied 12 months) 
4. Community Savings: Regional Financial Statistics of North Maluku

5. Statistical Indicators for the City of Ternate

The table above explains that there is positive progress in the direction of the data on GRDP, Total Population, and Per Capita Income of the City of Ternate. Therefore, there is the substance of the first problem if the GRDP of a region is high, then the local community can have a relatively high per capita income level, which can be hypothesized to affect the consumption level of the people of Ternate City. A high level of income per capita can lead to high demand for an item which will trigger inflation, and when inflation rises, it can affect public consumption. If the income per capita is high, it can also be assumed that people have savings so that the more money people save can also affect the level of consumption.

Based on the background description above, the formulation of the research problem to be achieved is as follows:

1. Does the income per capita affect people's consumption in Ternate City?

2. Does inflation affect public consumption in Ternate City?

3. Does saving affect people's consumption in Ternate City?

4. Do income per capita, inflation, and savings together affect public consumption in Template City?

\section{Literature Review}

\subsection{Consumption Theory}

When viewed again, the variables that affect consumption are actually not only income, but there are other variables that affect people's consumption (a person) including socio-economic variables, price levels, tastes, interest rates, and so on. A person's income can be divided into two, namely per capita income and real income. Nominal income is the income that a person receives in a person's nominal amount. Meanwhile, real income is income whose amount has been deflated by changes in the prices of goods and services. Real income is the most realistic indicator used to measure a person's level of welfare. Below, some theories of consumption can be explained, where in this discussion the size of consumption is determined by other variables besides income (Bakti, 2009).

According to Mankiw (2007), the notion of consumption is the expenditure of goods and services by households. What is meant by goods are durable household goods, including equipment, vehicles, and items that do not last long, such as food and clothing? Service expenditures in question are goods that do not have a concrete form, for example, education. Several previous studies have supported and not supported the relationship between per capita income, interest rates and inflation with the level of public consumption. Such as studies: (Eryanto, 2018); (Monnin, 2014) both agreed to conclude that the inflation rate has a relationship with the level of public consumption, where the size of the consumption level is determined by the inflation rate that occurs. In contrast to the findings of Satriani, (2018), in his study he found that the inflation rate was not related to the size of public consumption. Meanwhile, Syukur and Rifianto (2013) looks at it from a different point of view, namely he finds that the level of political stability is precisely what determines the size of the level of public consumption.

The effect of household consumption is one of the macroeconomic variables. A person's consumption expenditure is the share of income that is spent. If the consumption expenditure of all people in a country is added up, the result is the people of that country's consumption expenditure.

On a macro-aggregate basis, public consumption expenditure is directly proportional to income per capita-the greater the income, the more consumption expenditure. The ratio of additional consumption expenditure to income is marginal desire to consume (marginal propensity to the consumer: MPC).

In societies whose economic life is relatively unstable, their MPC figure is relatively large, while their MPS figure is relatively small, meaning that if they get additional income, most of the additional 
income will be allocated for consumption. The opposite is true in societies whose economic life is relatively more stable. Rahardja (2001) studies found that consumption expenditure consists of government consumption (government consumption) "and household consumption. The underlying reasons are:

1. Household consumption expenditure has the largest position in total aggregate expenditure.

2. Household consumption is endogenous because the size of household consumption is related to other factors that are considered to influence it.

3. Therefore, we can develop economic models and theories that understand the relationship between consumption and other influencing factors. Theories and models continue to be known as the consumption model theory, which has proven useful for macroeconomic management.

4. The rapid development of society causes consumption behavior to change rapidly. This is another reason why the study of household consumption remains relevant.

\section{Methodology}

\subsection{Data Types and Sources Data Types}

The type of data in this study is time series data from 2009 to 2018. While the data source used is secondary data obtained from the Central Statistics Agency (BPS) of Ternate City and Bank Indonesia Representative of North Maluku which includes data on household consumption expenditures, income per capita, Inflation and Savings.

\subsection{Population and Sample}

Bukhari and Arikunto (2002) states that the population is the total number of units of analysis whose characteristics will be estimated and formally the population can be defined as a collection of objects, people or circumstances that at least have the same general characteristics. The population and sample in this study were the people of Ternate City.

\subsection{Data analysis method}

The analytical method used to test the hypotheses is multiple regression analysis. Hypothesis testing is carried out after the multiple regression model used is free from violations of classical assumptions, so that the test results can be interpreted correctly. The equations of the multiple regression model are as follows:

$$
\mathrm{Y}=\alpha \cdot B_{1} \mathrm{X}_{1}+B_{2} \mathrm{X}_{2}+B_{3} \mathrm{X}_{3}+\varepsilon
$$

Where: $\quad Y=$ Public Consumption

$\mathrm{X} 1=$ per capita income

$\mathrm{X} 2$ = Inflation

$\mathrm{X} 3$ = Savings

$\alpha=$ Insert (constant)

b1- b3 = Regression Coefficient

$\varepsilon=$ Distrubance error

The data Capital Income, Inflation and Savings are secondary data and are taken from BPS and data obtained annual data from 2009 to 2018, so that to obtain significant calculation results, the data is interpolated into data per semester. Secondary data processing in proving the hypothesis is used Eviews 10 software application. Further described the relationship of the following research variables: 
Figure 1 Frame Work

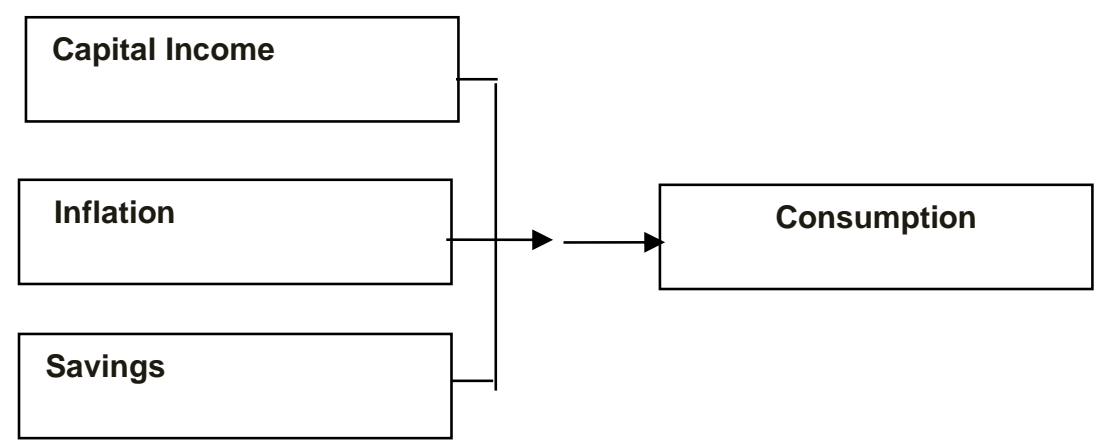

\subsection{Classic assumption test}

In addition to the statistical tests above, at the time of regression analysis, several problems often arise that are included in the classical assumption test, namely the presence or absence of normality, heteroscedasticity, multicollinearity and autocorrelation problems. will only be carried out with regard to multicollinearity, autocorrelation, normality, and heteroscedasticity.

\section{a. Multicollinearity test}

Multicollinearity test was conducted to determine whether there was a significant relationship between the independent variables. One way to detect multicollinearity is to test the correlation coefficient ( $r$ ) between the independent variables. As a rough rule of thumb, if the correlation coefficient is high enough that is above 0.85 then it is suspected that there is multicollinearity in the model. On the other hand, if the correlation coefficient is relatively low (0.85), it is suspected that the model does not contain elements of multicollinearity (Widarjono, 2005). Add to that the improvement in multicollinearity still produces a BLUE estimator because the BLUE estimator problem does not require the assumption of no correlation between independent variables. Multicollinearity only makes it difficult for us to get an estimator with a small standard error (Widarjono, 2005).

\section{b. Autocorrelation Test (Legrange Multiplier Method)}

Autocorrelation is a correlation between the residuals of one observation and the residuals of other observations. One method that can be used to detect autocorrelation problems is the BrueschGodfrey method or better known as the Lagrange Multiplier (LM) test. Detecting the occurrence of autocorrelation is based on: If the probability of chi square $>a=5 \%$, it means that Ho is accepted. If the probability of chi square is $r-59 \%$, it means that $\mathrm{Ho}$ is rejected. Where: $\mathrm{OH}$, there is no autocorrelation, there is autocorrelation.

\section{c. Normality assumption test}

This test aims to test whether in a regression model, the independent variable, the dependent variable, or both have a normal distribution or not. A good regression model is one that has a normal or close to normal data distribution. The method used to detect the Normality problem is to look at the pattern on the bar chart and the JB Probability value (Jarque-Bera), if the JB probability value is greater than 0.05 , it can be concluded that the residual value is normally distributed.

\section{d. Heteroscedasticity Assumption Test}

This test aims to test whether the regression model occurs or there is an inequality of variance from the residual from one observation to another. If the variance of the residual value from one observation to another is constant, it is called Homoscedasticity. And if the variance differs from one 
observation to another, then the method used to detect it is called Heteroscedasticity. heteroscedasticity problem is by Breusch-Pagan-Godfrey Test.

\section{Results and Discussion}

Geographical Condition of Ternate City Geographically, the city of Ternate is located between 0025'41.82 "-1021'21.78" North Latitude and between 12607'32,14-127026'23.12 "East Longitude, Geographically, the City of Ternate is limited by:

- North: Maluku Ocean

- South: Tidore Islands City and South Halmahera Regency

- East: South Halmahera Island

- West: Maluku Sea and Sulawesi Island

The Ternate City area is 5,709.58 km2, consisting of $162.03 \mathrm{~km} 2$ of land and 5,547.55 km2 of the sea.

\subsection{Population Condition of North Maluku Province}

The population of Ternate City based on population projections in 2016 is 218,028 people, consisting of 110,725 male residents and 07303 female residents. Compared to the projection of the total population in 2015, the population of Ternate has grown by 2.36 . Meanwhile, the size of the sex ratio in 2016, the population of women to population was 103.19 .

\subsection{Hypothesis test}

The results of annual data processing after being interpolated into semester data turned out to be autoclastic assumptions so that data testing was used by logaritma. The following is the result of data processing with the help of logarithms.

\subsection{Classic Assumption Testing}

Classical assumption testing, namely whether there is a problem of normality, heteroscedasticity, multicollinearity and autocorrelation. The research carried out in the study has a time dimension so that the classical assumption test units will only be carried out with regard to multicollinearity and autocorrelation.

\section{a. Multicollinearity Test}

Multicollinearity test is directed to decide if there is a huge connection between the free factors. One of the multicollinearity locations is to test the relationship coefficient $(r)$ between the free factors.

Table 4.1 Multicollinearity Test of Variance Inflation Factors

\begin{tabular}{llll}
\hline & Coefficient & Uncentered & Centered \\
\hline Variable & Variance & VIF & VIF \\
\hline LOG (PP) & 0,0211261 & 27259,35 & 7,439592 \\
\hline LOG(INF) & $9,85 E-04$ & 3,555695 & 1,328724 \\
\hline LOG(TAB) & 0,020417 & 18255 & 6,695423 \\
\hline \multicolumn{1}{c}{ C } & $9,73 E-01$ & 4590,448 & NA \\
\hline Source: Eviews & & &
\end{tabular}

Recognize the presence or nonattendance of multicollinearity in the Regre model, and it very well may be presumed that there is no multicollinearity between the autonomous factors in the relapse model. It is to take a gander at the VIF (Variance Inflation Factor) esteem if the VIF esteem $<10$, it very well may be presumed that there is no multicollinearity between the autonomous factors in the relapse model. 
Multicollinearity test results can be found in the Centered VIF section table. The VIF esteem for the variable pays per capita, saving has a number not in excess of 10248 . Since the VIF estimation of neither one of the variables is more prominent than 10 , it very well may be said that there is no multicollinearity in the three autonomous variable factors. In light of the old-style presumption prerequisites of straight relapse with OLS, an amazing direct relapse model is liberated from multicollinearity. In this manner, the above model is liberated from multicollinearity.

\section{b. Autocorrelation test}

Autocorrelation is a correlation between the residuals of one operation and the residual of other observations. One method that can be used to detect autocorrelation problems is the BrueschGodfrey method or better known as the Lagrange Multiplier (LM) test.

Table 4.2 Lagrange Multplier (LM) Autocorrelation Test Breusch-Godfrey Serial Correlation LM Test

\begin{tabular}{|c|c|c|c|c|}
\hline F-Statistic & & 2.155165 & Prob. $F(3,13)$ & 0,1425 \\
\hline $\begin{array}{l}\text { Obs* } \\
\text { Squared }\end{array}$ & R- & 6.643032 & $\begin{array}{lll}\text { Prob. } & \text { (3) Chi- } \\
\text { Square } & \end{array}$ & 0.0842 \\
\hline
\end{tabular}

Prob Value. F (2.11) of 0.1425 can likewise be known as the likelihood esteem F-check. Prob Value. $\mathrm{F}$ tally is more noteworthy than the alpha degree of $0.05(5 \%)$, in this way, in view of the theory test, $\mathrm{HO}$ is acknowledged, which implies that it doesn't happen; it tends to be reasoned that there is autocorrelation. Autocorrelation. Alternately, if the worth is Prob. F check is more modest than 0.05 , at that point.

\section{c. Ordinariness test}

The method used to detect the normality problem is to look at the pattern on the bar diagram and the JB (Jarque-Bera) Probability value; if the JB probability value is more significant than 0.05 , it can be concluded that the mutual value is usually distributed. In Jarque-Bera value obtained is 2.297756 with a probability of 0.316992 greater than 0.05 , so it can be concluded that the residue is usually distributed.

\section{d. Heteroscedasticity Test}

The method used to detect normality problems is the Middle Breusch-Pagan-Godfrey Test.

Table 4.3 Heteroscedasticity Test Heteroskedasticity Test: Breusch-Pagan-Godfr

\begin{tabular}{lcll}
\hline F-statistic & $\mathbf{0 . 9 2 6 0 7 3}$ & Prob.F(3,16) & $\mathbf{0 . 4 5 0 7}$ \\
\hline Obs R-5quared & 2.958979 & Prob. Chi-Square & 0.398 \\
\hline Scaled explained SS & 1,938989 & Prob. Chi-Square & 0.5852 \\
\hline
\end{tabular}

The results of testing the classic assumption of heteroscedasticity show that the probability value is 0.4507 , so it can be concluded that there is no heteroscedasticity problem in the regression model equation.

\section{e. Hypothesis test}

The results of the Multiple Regression calculation as proof of the hypothesis with the help of logarithms can be shown in the following table:

See the significant level of influence of each independent VA on the dependent variable will be described in the following test devotee: a. Statistical T-Test. The consequences of the t-test can be found in the table above if the worth is Prob. t-tally (appeared in Prob) is more modest than the blunder level (alpha) 0.05 (which has been resolved), it tends to be said that the autonomous variable significantly affects the reliant variable, though if the prob esteem. Totally is more noteworthy than the mistake pace of 0.05 ; it tends to be said that the autonomous variable has no critical impact on the needy variable. The log variable per capita pay has an at-tally estimation of 
7.14096 with a likelihood of 0.000 , which is more modest than 0.05 , so it very well may be reasoned that the log variable per capita pay has a positive relationship and significantly affects the Community Consumption log variable. The log expansion variable has an at-estimation of 0.875896 with a likelihood of 0.394 , which is more noteworthy than 0.05 , so it tends to be reasoned that the log swelling variable is emphatically connected and doesn't essentially influence the public utilization log variable. The log Savings variable has an at-estimation of -0.89879 with a likelihood of 0.3821 that is more prominent than 0.05 , so it very well may be reasoned that the log Savings variable has a negative relationship and has no critical impact.

Table 4.3 Test of Regression Equations

\begin{tabular}{|c|c|c|c|c|}
\hline Variable & $\begin{array}{c}\text { Coeffisien } \\
t\end{array}$ & Std. Error & t-Statistic & Prob \\
\hline LOG(PP) & 1,041238 & 0,0145812 & 7,14096 & 0,000 \\
\hline LOG(INF) & 0,027491 & 0,031386 & 0,875896 & 0,394 \\
\hline C & $-0,12843$ & 0,142888 & $-0,89879$ & 0,382 \\
\hline R-squared & 0.291786 & 0.985375 & 0,295816 & 0,771 \\
\hline Adjusted R-squared & 0.947697 & Mean dependent Var & & 15,70529 \\
\hline Adjusted R-squared & 0,93789 & S.D dependent var & & 0,261246 \\
\hline S.E. of regression & 0,065107 & Akaike dependent var & & $-2,44871$ \\
\hline Sum squared resid & 0,067823 & Schwartz Criterion & & $-2,4471$ \\
\hline Log likelihood & 28,48705 & Hannan-Quinn criter & & $-2,24956$ \\
\hline F-statistic & 96,6371 & Durbin-Watson Stat & & $-2,40983$ \\
\hline Prob (F-statistic) & 0,0000 & & & 0,836327 \\
\hline
\end{tabular}

\section{f. Test F (Igniting Beeara Test)}

Model unfaltering quality test or model feasibility test Feasible (strong) infers the evaluated model is possible to use to explain the trading of free factors to the closest factor. The results of the $\mathrm{F}$ test can be found in the table above. The prob regard. $\mathrm{F}$ (Statistic) as 06.0371 with a probability assessment of 0.000 not by and large the significance level of 0.00 , so it might be contemplated that the surveyed backslide model is functional to use to explain the effect of pay per capita (PP), development (INF) and speculation reserves (TAB) on the poor variable usage neighborhood).

\section{g. Derteminated coefisien (R2)}

This test is used to measure the closeness of the relationship from the model used. The R-Square value in the table above is 0.947697 , indicating the proportion of the log variable's influence (Per Capita Income), log (Inflation), and log.

(Savings) against the log variable (Public Consumption) of $94.76 \%$. The variable of public consumption can be explained as being influenced by variables of income per capita, savings, and inflation. Meanwhile, 5.24\% was explained by other variables which were not researched.

The Multiple Regression Equation in this study is obtained as follows: Log KM $=0.291700+\log$ 1.041238 (PP) + Log 0.027491 (INF) - Log 0.12843 (TAB).

\section{Conclusion}

Income variable per capita has a positive and significant impact on the consumption of the people of the city of Ternate. The people of Ternate City tend to increase their consumption if there is an increase or addition to their income. The inflation variable has an insignificant positive effect on the consumption of the people of Ternate City. The people of Ternate City tend not to be affected by changes in the percentage of up / down inflation in the desire to consume a product or service. The 
ability of the bell power of the people of Ternate City who are still enthusiastic when prices soar high is assumed to be the cause of the high cost of living in the city of Ternate so that inflation does not have a significant influence on people's consumption. Savings variable has no significant negative effect on the consumption of the people of Ternate City. Some households tend to consume credit goods so that the monthly income that enters the bank account is the residual and fixed consumption paid to the debtor (bank or financial institution). The insignificant results on public consumption empirically prove that the effect of the saving variable will continue to reduce people's desire to consume goods and services. Savings in bank accounts are assumed to be motivated in case of sudden needs.

\section{References}

1. Bakti, M. (2009). Speech disfluencies in simultaneous interpretation. De Crom, Dies (ed.).

2. Bukhari, F. B. S. S. Arikunto, S. (2002). Prosedur Penelitian. Jakarta: PT Rineka Cipta. Al-Utsmin, Shalih Syaikh Muhammad. Problematika Remaja dan Solusinya Dalam Islam. Solo: At-tibyan. Broto, Suryo Samadi. 1993. Psikologi Perkembangan. Yogyakarta: Rake Saran. Darajat, Zakiyah. 1978, Membina Ni.

3. Dumairy. (2004). Perekonomian Indonesia. Cetakan Kelima. Penerbit Erlangga. Jakarta.

4. Eryanto, M. B. (2018). Analisis Faktor-Faktor yang mempengaruhi konisumsi masyarakat di Indonesia Tahun 2009.1 - 2017.II. Jurnal Skripsi. Program Studi limu Ekonomi Studi Pembangunan. Fakultas Ekonomi dan Bisnis. Universitas Muhammadiyah Surakarta. Dipublikasikan.

5. Guritno, M. (1998). Teori Ekonomi Makro. Yogyakarta: STIE.

6. Mankiw, N. G. (Ed.). (2007). Monetary policy (Vol. 29). University of Chicago Press.

7. Monnin, P. (2014). Inflation and income inequality in developed economies. Council of Economic Policies Working Paper 2014/1.

8. Nanga, M. (2005). Makro Ekonom: Teori, Masalah dan Kebijakan. Edisi Kedua, Raja Grafindo Perseda, Jakarta.

9. Rahardja, I., Welch, A. B., \& Hebbes, M. (2001). U.S. Patent No. 6,298,829. Washington, DC: U.S. Patent and Trademark Office.

10.Raharja, Prathama dan Marunung, M. (2004). Teori Ekonomi Makro: suatu pengantar. Edisi Kedua. Fakultas Ekonomi Universitas Indonesia, Jakarta.

11.Sadono, S. (2008). Makro Ekonomi, Teori Pengantar. Penerbit PT. Raye Grafindo Persada, Jakarta.

12.Satriani, A., Catalano, M., \& Scalcione, E. (2018). The role of superabsorbent hydrogel in bean crop cultivation under deficit irrigation conditions: A case-study in Southern Italy. Agricultural Water Management, 195, 114-119.

13.Sukirno, S. (2003). Pengantar Teori Makto Ekonomi. Perierbit PT Raje Grafindo Perada, Jakarta.

14.Syukur, M., \& Rifianto, S. P. A. (2013). Jagung manis. Penebar Swadaya Grup.

15.Widarjono, A. (2005). Ekonometrika Teori dan Aplikasinya. Yogjakarta: Ekonisia. 